them hitherto. P. N. Zealandia is not hermaphrodite. I examined several males, which differ in no essential points in their structure from those of $P$. capensis. Like those of $P$. capensis, they are less numerous than the females, and Capt. Hutton has been unlucky enough not to meet with any amongst the twenty specimens examined by him. The jaws of $P . N$. Zealandice are further, I believe, developed just as are those of P. capensis. At least I saw that the earliest stages corresponded, and recognised the first pair of members of the embryo in $P$. $N$. Zealandice in the stage in which they are not yet turned inwards to become foot jaws. I have prepared a more extended answer to Capt. Hutton's paper with an account of my own observations on P. N. Zealandize for the Ann. and Mag. of Nat. Hist., but as this cannot probably be published immediately, I should be much obliged if you would insert this reply in NATURE.

H. N. Moseley,

Naturalist to H.M.S. Challenger

\section{The Age of the Rocks of Charnwood Forest}

IT is no doubt to be regretted that Mr. Woodward, misled by insufficient authority, should have introduced, in his excellent work on the geology of England and Wales, still further confusion into the maltreated old rocks of Charnwood Forest, but I doubt whether their age is quite so certain as Prof. Hull seems to think. I fully agree with him that there is not a particle of evidence for their Laurentian age, and that their syenites and horrblendic granites cannot be correlated with the hornblendic gneiss of the Malverns, but I must demur to his grouping them with the Cambrian rocks of the Longmynds or of Llanberis. The authority of Prof. Sedgwick is great, but it must be remembered that the term Cambrian with him included far more than in the nomenclature of the Geological Survey, and I am not aware that he ever committed himself to the Charnwood rccks being equivalent to his Lower Cambrians. Except a slight lithological resembiance of scme Charnwood rocks to those of Harlech and Llanberis, and a still slighter to Longmynd rocks, there is really nothing in favour of this special correlation. One point, however, there is which may give some clue to their age, which does not seem to have been much noticed hitherto, probabiy because the facts have been strangely overlooked in the Geological Survey description of the district. It is that beds of coarse volcanic agglomerate and ash abound among the Charnwood series. Finrther, the resemblance of the rocks as a whole (when rot unisually metamorphosed) is very close to the "green slate and porphyry series" (or Borrowdale rock") of the Lake District. Compared with the Welsh rocks, they are far more like those of Cader-Idris than of Llanberis. With these there is scarce any litholosical resemblance, but if I mixed my Charnwood collection with those from the other two localities, e:pecially the former, I should have great difficulty in separating many specimens. It scerrs then to me far more likely that this great volcanic activity in the Charnwood district should have corresponded in time with that in the Lake District or with some part of that in Wales, than that it should have happened in the age of the Harlech, Llanberis, and Longmynd groups, where we have no evidence of any volcanic disturbance. The argument may be summed up thus, as it secms to me :- The Charnwood rocks are old, so are both the competing groups; they are unfossiliferous, so are both; they are cleaved, so are both; they contain evidence of great volcanic action, so do the Borrowdale series, and not the Welsh Lower Cambrians. One point for the former. The general correspondence of their strike with that of the Borrowdale series under Ingleborough may also perhaps count for something.

\section{St. John's College, Cambridge, November 25}

T. G. BONNEY

THovgri the discussion of the age of the rocks of Charnwood Forest is not likely in the present state of our knowledge to lead to any useful result, there are still a few points in Prof. Hull's letter on the subject which seem to call for remark. In the first place the late Prof. Jukes was by no means so strongly in favour of the Cambrian age of these rocks as Prof. Hull states. Prof. Jukes' words, in Potter's (not Porter's) "History of Charnwood Forest" are as follows :- "It is therefore uncertain whether they (the rocks of Charnwood) belong to the Devonian, Silurian, or Cambrian systems, the probability only being in favour of the latter." Secondly, the Cambrian of Sedgwick includes a great deal more than the Cambrian of the Geological Survey, and therefore there is not the perfect unanimity between these two authorities that Prof. Hull's remarks would lead us to believe. Thirdly, if lithological resemblance is to go for anything, it may be used directly against the Cambrian age of the rocks. On the western side of the forest we find sheets of crystalline rock and beds of highly altered conglomerates and breccias, which have a suggestive likeness to the lava fluws and ash beds of the green slate and porphyry series of the Lake District. I don't say the resemblance proves anything, but it is worth quite as much as the similarity between the slates on the east side of the forest and the slates of Llanberis. Mr. Bonney has also called attention to the fact that the strike of the Charnwood Forest rocks is the same as that of the Volcanic Series in the Lake Country, when that group is last seen. Again, it is far from certain that the rocks of Charnwood Forest are all of the same age. I recollect seeing many years ago some sections (of which I am afraid I have kept no record) that seemed to show that some of the bosses of Dioritic rock near Markfield were older than the slates that surrounded them. If this be so, perhaps these crystalline hills may be the projecting points of a nucleus of similar rock that underlies the whole area, and which may be Laurentian in age. The rocks are not gneiss, but I know of no reason why the equivalents of the rocks of the Hebrides must be gneiss all the world over; they are, however, rich in hornblende, and so are the Hebridian rocks. With all these possibilities before us, I am afraid it will be hard to arrive at that enviable state of security which Prof. Hull seems to have been in when he penned his letter.

A. H. Green

I AM pleased to find in NATURE, vol. xv., p. 78 , a letter from Prof. Hull, with reference to the age of our Charnwood Forest rocks. He writes against their assignment by Mr. II. B. Woodward, in his "Grology of England and Wales," to the Laurentian period (see p. 24).

But, in fact, as Prof. Huil himself points out, we also find on p. 30 a statement that part of the series may belong to the Cambrian epoch.

It would appear that as Mr. Woodward is not personally acquainted with the region, he has endeavoured to give the views of the various authors whom he knows to have written on the subject, and as these are conflicting, and based upon little personal work, it is no wonder that he has been led astray.

I do not think sufficient importance has been attached to the study of this isolated outcrop of old rocks. We can trace its continuation to the south and south-east for a considerable distance, and I would venture to suggest the possibility of a flexure or spur in this direction connecting with the old palæozoic ridge for which we have lately been fishing in the Wealden. In my "Geology of Leicestershire and Rutland," which will shortly be published, there will be tound some fine photographs of the principal quarries and natural outcrops of the Charnwood rocks; and $Y$ have there given the reasons which induce me on the whole to refer the main mass of the rocks to neither Laurentian nor Cambrian, but to the Silurian period. The evidence is but scanty however, but a balance of probabilities at the best. As to Sedgwick's determination of the region, we nust remember that much that he the:1 calied Cambrian has since been assigned to Lower Silurian.

Town Museum, Leicester, November 24

\section{Minimum Thermometers}

SOME time ago a correspondence appeared in NATURE (vol. vi. pp. 122, 142, 221) on the subject of moisture deposited in minimum thermometers exposed on the grass. As I was at the time much annoyed with this myself I took up every hint I could get in the matter, though I must confess with indifferent success. I tried for a long time india-rabber packing, with sealing-wax, \&c., of varying coats, as advised, but still moisture insinuated itself.

At last I bethought myself of a cork packing. I cut a piece of cork so as to fit tightly round the neck of the thermometer tube, then inserted the tube and packing into the glass case-the cork packing being about a quarter of an inch long. The exposed end of the cork I covered with two or three coats of asphalte, as used on microscopic slides. At first a slight bubbling was seen through the asphalte, but soon disappeared, and a fine uniform surface at last set in. The thermometer has now been in use for several months, and not the least trace of moisture has ever been seen within the cases, although moisture has been abundant, especially for the last three months. The process is simple enough, and I venture to send it to you, hoping that it 